\title{
Relationship between Profile and Attitude of Rural Women towards Girls Higher Education
}

\author{
Y. S. Patil*, D. D. Suradkar and J. M. Deshmukh \\ Department of Extension Education, College of Agriculture, Latur (M.S.), India \\ *Corresponding author
}

\begin{tabular}{l} 
K e y w o r d s \\
$\begin{array}{l}\text { Profile, Rural } \\
\text { women, Girls } \\
\text { Higher education, } \\
\text { Relationship }\end{array}$ \\
\hline Article Info \\
$\begin{array}{l}\text { Accepted: } \\
\text { 22 June } 2020 \\
\text { Available Online: } \\
\text { 10 July } 2020\end{array}$ \\
\hline
\end{tabular}

\begin{abstract}
A B S T R A C T
The present study was conducted in Latur district, randomly selected from Marathwada region of Maharashtra state during the year 2019-2020. From Latur district, three tehsils were selected randomly viz. Chakur, Latur and Renapur. From each selected tehsil, four villages were selected randomly. From each selected village, 10 rural women were selected as respondents purposively on the basis of their daughters studying in secondary or higher secondary educational institutions. In this way total 120 rural women were selected as respondents for the present study. These selections were done by using simple random sampling method for the purpose of the study. Profile of rural women depicted that majority $(66.66 \%)$ of the respondents were middle aged, 57.50 per cent had high school level of education, 95.83 per cent of the respondents were married, 40.00 per cent belonged to OPEN category, 56.66 per cent were of them were from medium size of family, 81.66 per cent were from nuclear family, 63.33 per cent respondents had cultivation as their major occupation, 34.16 per cent had semi-medium size of land holding. It was observed that, majority $(93.34 \%)$ of the respondents were having medium annual income, 60.83 per cent of them having medium social participation and 65.83 per cent of them had medium level of mass media utilization. The results also showed that independent variables viz. age showed negative and significant relation with attitude, while education, marital status, occupation, annual income, social participation and mass media utilization showed positive and significant relation with attitude. And category, family size, family type and land holding do not show significant relation with attitude.
\end{abstract}

\section{Introduction}

Education has always been important in the development of a nation. It plays a vital role in the development of human race and nation. It is the light that shows the way, medicine that cures and the key which opens all doors. It is most powerful tool for change and can put girls on the path of economic and social empowerment with the knowledge, skill and self-confidence which is necessary to participate fully in the development process. Although women are vital human resources; their economic, educational, social and political empowerment hastened the pace of social development. The importance of educating girls to economic growth is supposed by the literature. It is widely 
accepted that investing in girl's education has important externalities for improving general social welfare, leading them to marry later and have fewer and healthier children, thereby reducing both maternal and infant morbidity and mortality rates (Sheila 2007). In fact, education improves health, productivity, bringing about empowerment and reduces negative features of life. Rural women's education plays an important role in the social progress. For that, education will be used as an agent of basic change in the status of rural women.

Higher education helps the girl's not only in gaining knowledge but also enables her to earn a living. It helps them to have a better understanding of social and political process beyond the home in far reaching social structure and makes her a wise citizen with effective social and political action. It also helps them to become mentally and emotionally stronger and to face challenges and overcome obstacles in life and to become complete women.

\section{Materials and Methods}

The present study was conducted in Latur district, randomly selected from Marathwada region of Maharashtra state during the year 2019-2020. From Latur district namely three tehsils were selected randomly viz. Chakur, Latur and Renapur. From each selected tehsil, four villages were selected randomly. From each selected village, 10 rural women were selected as respondents purposively on the basis of their daughters studying in secondary or higher secondary educational institutions. In this way total 120 rural women were selected as respondent for the present study. These selections were done by using simple random sampling method for the purpose of the study. For estimating profile of rural women, Ex-post facto research design was adopted in this study. The data were collected with the help of pretested interview schedule. The statistical methods and tests such as frequency, percentage, mean, standard deviation, correlation coefficient was used for the analysis of data.

The main objectives of this study to collect the Profile of rural women and study about Relationship between profile of rural women and their attitude towards girl's higher education.

\section{Results and Discussion}

\section{Profile of rural women}

Age

The data presented in table 1 shows that majority $(66.66 \%)$ of the respondents were observed in middle age group, followed by young (24.16\%) and old (09.18\%) age.

\section{Education}

It depicts that 57.50 per cent of the respondents had high school level of education. Whereas, 20.00 per cent, 10.83 per cent and 06.66 per cent, 04.16 per cent and 00.85 of the respondents who were having education up to middle school, illiterate, primary school, graduate and read and write only respectively.

\section{Marital status}

It was revealed that majority $(95.83 \%)$ of the respondents were married, whereas only 04.17 per cent of them were widow.

\section{Category}

It was found that more than two third $(40.00 \%)$ of the respondents belonged to OPEN category, followed by Other Backward Class (21.66\%), Scheduled Tribe (15.00\%), 
Scheduled Caste (14.16\%) and Nomadic Tribe $(09.18 \%)$ respectively.

\section{Family size}

It was reported that more than half $(56.66 \%)$ of the respondents belonged to medium sized family, whereas 26.68 per cent were from small sized family and 16.66 per cent were from large sized family.

\section{Family type}

Table 1 indicates that majority $(81.66 \%)$ of the respondents belonged to nuclear family and only 18.34 per cent belonged to joint family.

\section{Occupation}

It is evident from table 1 that more than half $(63.33 \%)$ of the respondents were engaged in cultivation, whereas 20.00 per cent were labour, 07.50 per cent were engaged in service, 05.00 per cent were engaged in independent profession, 03.32 per cent were engaged in business and remaining 00.85 per cent engaged in caste occupation.

\section{Land holding}

It is revealed that more than one third $(34.16 \%)$ of the respondents had semimedium land holding i.e. 2.01 to 4.00 ha land holding, whereas 30.00 per cent had small i.e. 1.01 to 2.00 ha, 29.16 per cent had marginal i.e. 1.00 ha, 05.83 per cent had medium i.e. 4.01 to 10 ha and only 00.85 per cent had above 10 ha.

\section{Annual income}

It is depicted that majority (93.34\%) of the respondents had annual income in between Rs 48001/- to Rs 400000/-, whereas 06.66 per cent of the them had annual income above Rs 400000/- and no single respondent were observed in annual income up to 48000/income group.

\section{Social participation}

The data reported in table 1 showed that nearly two third $(60.83 \%)$ of the respondents belonged to medium social participation, followed by low (20.83\%) and high (18.34\%) respectively.

\section{Mass media utilization}

It is evident that 65.83 per cent of the respondents had medium mass media utilization, followed by 23.34 per cent had low and 10.83 per cent had high respectively.

\section{Relationship between profile of rural women and their attitude towards girl's higher education}

One of the objectives of the study is to delineate the relationship between profile of rural women and their attitude towards girl's higher education. The data were subjected by correlation coefficient.

In order to find out the relationship between profile of rural women and their attitude towards girl's higher education, correlation coefficient was worked out and have been presented in table 2 and the results revealed that out of eleven independent variables, six variables had exhibited positive and statistically significant relation and one had negative and statistically significant relation with the attitude i.e. age had negative and statistically significant relation, while education, marital status, occupation, annual income, social participation and mass media utilization had positive and statistically significant relation with the attitude. And category, family size, family type, land holding not showed significant relation with attitude. 
Table.1 Profile of rural women $(\mathrm{N}=120)$

\begin{tabular}{|c|c|c|c|}
\hline & Category & Frequency & Percentage \\
\hline \multirow{3}{*}{ Age } & Young age (Up to 32 years) & 29 & 24.16 \\
\hline & Middle age ( 33 to 42 years) & 80 & 66.66 \\
\hline & Old age (Above 42 years) & 11 & 09.18 \\
\hline \multirow[t]{7}{*}{ Education } & Illiterate & 13 & 10.83 \\
\hline & Can read only & 00 & 00 \\
\hline & Can read and write & 01 & 00.85 \\
\hline & Primary & 08 & 06.66 \\
\hline & Middle & 24 & 20.00 \\
\hline & High school & 69 & 57.50 \\
\hline & Graduate & 05 & 04.16 \\
\hline \multirow[t]{2}{*}{ Marital status } & Married & 115 & 95.83 \\
\hline & Widow & 05 & 04.17 \\
\hline \multirow[t]{5}{*}{ Category } & Open & 48 & 40.00 \\
\hline & Other Backward Class (OBC) & 26 & 21.66 \\
\hline & Nomadic Tribe (NT) & 11 & 09.18 \\
\hline & Scheduled Tribe (ST) & 18 & 15.00 \\
\hline & Scheduled Caste (SC) & 17 & 14.16 \\
\hline \multirow[t]{3}{*}{ Family size } & Small size (Up to 4$)$ & 32 & 26.68 \\
\hline & Medium size (5 to 8 ) & 68 & 56.66 \\
\hline & Large size (Above 8) & 20 & 16.66 \\
\hline \multirow[t]{2}{*}{ Family type } & Nuclear & 98 & 81.66 \\
\hline & Joint & 22 & 18.34 \\
\hline \multirow[t]{6}{*}{ Occupation } & Labour & 24 & 20.00 \\
\hline & Caste occupation & 01 & 00.85 \\
\hline & Business & 04 & 03.32 \\
\hline & Independent Profession & 06 & 05.00 \\
\hline & Cultivation & 76 & 63.33 \\
\hline & Service & 09 & 07.50 \\
\hline \multirow[t]{5}{*}{ Land holding } & Marginal (Up to 1.00 ha.) & 35 & 29.16 \\
\hline & Small (1.01 to 2.00 ha.) & 36 & 30.00 \\
\hline & Semi-medium (2.01 to 4.00 ha.) & 41 & 34.16 \\
\hline & Medium (4.01 to 10.00 ha.) & 07 & 05.83 \\
\hline & Large (Above 10.00 ha.) & 01 & 00.85 \\
\hline \multirow[t]{3}{*}{ Annual income } & Low income (Up to $48000 /-)$ & 00 & 00 \\
\hline & $\begin{array}{l}\text { Medium income } \\
(48001 \text { to } 400000 /-)\end{array}$ & 112 & 93.34 \\
\hline & High income (Above 400000/-) & 08 & 06.66 \\
\hline \multirow[t]{3}{*}{ Social participation } & Low participation (Up to 9) & 25 & 20.83 \\
\hline & Medium participation (10 to 14 ) & 73 & 60.83 \\
\hline & High participation (Above 14) & 22 & 18.34 \\
\hline \multirow[t]{3}{*}{ Mass media utilization } & Low (Up to 5) & 28 & 23.34 \\
\hline & Medium (6 to 10$)$ & 79 & 65.83 \\
\hline & High (Above 10) & 13 & 10.83 \\
\hline
\end{tabular}


Table.2 Relationship between independent variables and dependent variable

\begin{tabular}{|c|c|c|}
\hline SL. No. & Variables & 'r' value \\
\hline $\mathbf{1 .}$ & Age & $-0.357^{* *}$ \\
\hline $\mathbf{2 .}$ & Education & $0.593^{* *}$ \\
\hline $\mathbf{3 .}$ & Marital status & $0.240^{*}$ \\
\hline $\mathbf{4 .}$ & Category & $-0.003^{\mathrm{NS}}$ \\
\hline $\mathbf{5 .}$ & Family size & $0.021^{\mathrm{NS}}$ \\
\hline $\mathbf{6 .}$ & Family type & $0.016^{\mathrm{NS}}$ \\
\hline $\mathbf{7 .}$ & Occupation & $0.232^{*}$ \\
\hline $\mathbf{8 .}$ & Land holding & $0.159^{\mathrm{NS}}$ \\
\hline $\mathbf{9 .}$ & Annual income & $0.225^{*}$ \\
\hline $\mathbf{1 0}$ & Social participation & $0.229^{*}$ \\
\hline $\mathbf{1 1}$ & Mass media utilization & $0.461^{* *}$ \\
\hline
\end{tabular}

$*$ and ** correlation are significant at the $0.05 \%$ and $0.01 \%$ level respectively.

NS - Non significant

The conclusions of the study are as follow

From the above results it was concluded that majority of the respondents belonged to medium age group, high school level of education, married marital status, OPEN category, medium size of family, nuclear type of family and they had cultivation as their major occupation, semi-medium size of land holding. It was also observed that, majority of the respondents were having medium annual income, medium social participation and medium level of mass media utilization.

It was depicted that independent variables like age showed negative and significant relation with attitude, while education, marital status, occupation, annual income, social participation and mass media utilization showed positive and significant relation with attitude. And category, family size, family type and land holding do not show significant relation with attitude.

\section{References}

Akpede, N., Eguvbe, A. O., Akpama, O., Asogun, A. D., Momodu, M. and Igbenu, N. E. 2018. Parent's attitude and practice towards the girl child education in Esan West local government area of Edo state in Nigeria. Insight Medical Publishing Journal of Women's Health and Reproductive Medicine. 2 (1): 3.

Ashvini, V. K. 2014. Attitude and perception of rural women towards girl's education. M.Sc. (Agri.) Thesis (Unpub.), Vasantrao Naik Marathwada Krishi Vidyapeeth, Parbhani.

Kavitha, M. and Godwin, P. S. 2014. Rural girl student's attitude towards education. Journal of Business Management and Social Sciences Research. 3 (10).

Mohyuddin, A., Chaudhry, Hafeez-urRehman and Ambreen, M. 2012. Changing attitude towards female education. International Journal of Scientific and Engineering Research. 13 (12).

Nita, D. 2010. Role of women in farm and family decision making. M.Sc. (Agri.) Thesis (Unpub.), Dr.Panjabrao Deshmukh Krishi Vidyapeeth, Akola.

Pritam, D. S. 2017. Farm women attitude towards girl's higher education. M.Sc. (Agri.) Thesis, Dr.Panjabrao Deshmukh 
Krishi Vidyapeeth, Akola.

Sheila, K. M. 2007. Determinants of parental attitudes regarding girl's education in rural India. M.Sc. Thesis, Georgetown Public Policy Institute, Washington, D. C.

Uzma, E. 2017. Attitude of parents towards girl's education. Saudi Journal of Medical and Pharmaceutical Sciences. 3 (3A): 145-147.

Yashomati, K. 2008. Attitude of rural women towards girl's education. M.Sc. (Agri.) Thesis, Marathwada Agricultural University, Parbhani.

\section{How to cite this article:}

Patil, Y. S., D. D. Suradkar and Deshmukh, J. M. 2020. Relationship between Profile and Attitude of Rural Women towards Girls Higher Education. Int.J.Curr.Microbiol.App.Sci. 9(07): 2670-2675. doi: https://doi.org/10.20546/ijcmas.2020.907.314 